\title{
Comentários sobre a questão agrária catarinense
}

José Walter Dresch*

Inicialmente gostaria de dizer que, para mim, a compreensão de políticas públicas está aliada a um projeto de sociedade que a gente sonha, é um investimento do Estado para aquilo que a gente quer para o futuro da sociedade. E falando de Santa Catarina, quando a gente fala de agricultura familiar, qual é o conceito que nós temos de agricultura familiar? Não é uma agricultura pobre e apenas de subsistência. Deve-se pensar em agronegócios familiares. A única coisa que difere os negócios na agricultura é que uma agricultura contrata mão-de-obra, que faz trabalho, que faz a produção com mão-de-obra comprada, e a outra que trabalha com a mão de obra familiar, com o seu conjunto. Mas existe uma grande massa de assalariados em Santa Catarina que foi se acumulando ao longo do tempo. Eu queria aproveitar para dizer o que aconteceu nos últimos quinze a vinte anos. Vou levantar questões sobre a realidade concreta.

\section{$* * *$}

O primeiro ponto a destacar é que Santa Catarina, historicamente, desenvolve a atividade suinícola. Contudo, nos últimos vinte anos um grande número de produtores abandonou a atividade e/ou ela passou a ser secundária na propriedade. Nos anos de 1990, existiam em torno de 59 mil famílias envolvidas nessa atividade, hoje há um pouco menos de oito mil famílias. E quantas vezes se multiplicou o volume de produção nesses últimos vinte anos?

Presidente da FETAESC.

Geosul, Florianópolis, v. 29, ESPECIAL, p 155-159, jul./dez. 2014 
DRESCH, J.W. Comentários sobre a questão agrária catarinense.

O segundo ponto é que nós temos hoje em Santa Catarina, de 33 a 34 mil propriedades que não têm mais sucessão ou têm a sucessão ameaçada. O pai, a mãe já tem mais de 45 anos, próximo dos 50 anos, e os filhos já foram embora, eles não estão mais lá na propriedade, eles já se mandaram para fazer outro trabalho lá fora. E aí a gente diz o seguinte: Bom, se nós tivemos 59 mil famílias e hoje temos menos de oito mil, e a produção na suinocultura aumentou muito, o número produzido aumentou muito, então não vão fazer falta essas outras 33 ou 34 mil famílias. Essas propriedades passarão a englobar as grandes fazendas, as grandes propriedades e por aí afora.

O terceiro ponto diz respeito ao papel da tecnologia. Muito se afirma que ela é um mal. Isso é equívoco. É necessário saber de que forma isso chega às propriedades da agricultura dos nossos estados. Falando aqui do nosso estado de Santa Catarina, por exemplo, EMBRAPA e EPAGRI, elas têm um papel fundamental, importantíssimo para o desenvolvimento da agricultura e a boa aplicação das políticas públicas. Contudo, Santa Catarina deve ter uns 2.150 técnicos da EPAGRI e nessa empresa há um programa de demissão incentivada, que tira 718 técnicos do campo e contrata sessenta, setenta. Como é que fica a questão da assistência rural e da pesquisa? Por exemplo, no Paraná o agricultor que não produzir, não tiver produção em torno de mil litros de leite/dia, em torno de trinta mil litros/mês, ele, num curto espaço de tempo, estará fora do processo de produção, não está mais, ele sai fora, jogam-no para fora. Em Santa Catarina, nós temos 85\%, 90\% que produz menos de quinhentos litros. Quem vai dar assistência ao produtor quando as grandes empresas de Goiás, de Minas Gerais vêm instalar unidades de produção em Santa Catarina exigindo escala de produção?

O quarto aspecto que gostaria de ressaltar é a questão da política pública do chamado "mais alimento", conhecidos por todos nós e que veio junto com o PRONAF. O que é de fato essa política? O que é que ela é? Se a gente der uma olhada talvez é mais caminhão, é mais trator, mais dívida, mais agricultor não 
DRESCH, J.W. Comentários sobre a questão agrária catarinense.

conseguindo pagar conta, mais especulador comprando trator por $50 \%$ do valor, mais caminhão sendo vendido. Um caminhão que vale $\mathrm{R} \$ 100,000,00$ está sendo vendido por $\mathrm{R} \$ 60,000,00$, um pouco mais. Mas por quê? Em contrapartida, na área da avicultura, qual é o capital que tem o agricultor ou a agricultura do Sul do Brasil para fazer um investimento de um milhão de reais, um milhão e duzentos mil para continuar num processo produtivo de frangos? Outra questão é por que não se descentraliza a produção? Por que tudo tem que ser industrializado em Chapecó e Concórdia? Isso afeta o consumo. Por exemplo, como é que está a questão do consumo de leite aqui na grande Florianópolis e quem fornece e de onde vem?

Isso para mim é uma falta de visão clara de política pública, de investimento do estado, no sentido de garantir que a sociedade possa viver de forma diferente. Aí nós temos uma questão que estava muito em debate até a semana passada, quem sabe volte agora até final do mês. Quando a gente fala de política pública na educação, na saúde, no desenvolvimento da sociedade se fala bastante, por exemplo, de uma questão que cuida do investimento social chamado Bolsa Família e que isso tem sido pano para manga em muitos momentos de discussão. Os contra e os a favor. E a gente faz uma pergunta seguinte: A gente deve continuar fazendo investimento só no Bolsa Família? O que é que a gente espera dessa discussão para frente, no sentido de políticas públicas e, principalmente, quando a gente fala de questões agrárias neste país?

A gente, às vezes, não quer compreender, ou tem dificuldade para compreender, ou tem divergências inclusive de posicionamento, em entender pelo menos da concepção da instituição da qual eu faço parte, do que é essa questão agrária? Eu queria me ater um pouco a isso. Primeiro, porque eu não sou capaz de concordar e pelos menos até o presente momento eu não encontrei uma justificativa para isso, que a concentração seja ela de terra, seja ela de produção, e que isso gere o resultado positivo para a sociedade. Quero deixar muito claro aqui que acho que o grande 
DRESCH, J.W. Comentários sobre a questão agrária catarinense.

produtor, que o agronegócio, compreende tanto a pequena propriedade, quanto a pequena indústria do meio rural.

Não quero aqui dizer que a grande produção seja o grande problema da sociedade, do mundo, mas quero dizer que, para a grande produção ou para grande propriedade, a política pública não tem muita importância, o posicionamento de governo, acho que não tem importância. Até porque se nós olharmos para uma propriedade que tem vinte mil hectares certamente lá tem, se for na produção de grãos, um agrônomo e uma série de pessoas ligadas a essa área para que possa orientar a produção dessa propriedade com vinte mil hectares.

É diferente de uma propriedade com vinte hectares, que não vai ter as mesmas condições. Então se confunde o papel do Estado. Onde é que o Estado entra nesse momento? Isso vale para produção de grãos, vale para produção de frango, de leite, enfim, para qualquer produção. Acho que essa é uma questão que preciso ter muito presente para não ficarmos imaginando que a grande propriedade, que o volume de produção acumulado, seja um mal para a sociedade; que isso faça mal, que isso prejudique, que isso atrapalhe. Agora, é necessário compreender que a pequena produção, aquela feita ainda pelo conjunto familiar, pelas pessoas, precisa de um tratamento diferenciado. E aí é que entra um posicionamento do Estado, no sentido das tecnologias, do avanço tecnológico que é importantíssimo, que cumpriu um papel muito importante em todos os sentidos, que isso é interessantíssimo para o desenvolvimento.

Até porque as políticas públicas elas olham às vezes num macro, no grande, por cima, mas não olham aquilo que acontece lá na propriedade do interior, lá no município pequeno. Temos municípios aqui no nosso estado e em outros estados que tem 2100 habitantes, que poderiam se desenvolver. Então, lá é que eu acho que precisa de políticas públicas, para que de fato as pessoas tenham condições de continuar desenvolvendo o estado de Santa Catarina. Eu queria, inclusive, parar por aqui, porque acho que seria muita pretensão da minha parte querer, como se diria, num 
DRESCH, J.W. Comentários sobre a questão agrária catarinense.

linguajar bem simples, ensinar Pai Nosso para Vigário.

Fico aqui à disposição para uma eventual pergunta, de forma modesta para poder responder alguma dúvida, alguma questão que eu pudesse contribuir com esse debate. Até porque vocês estão muito bem servidos pelos dois palestrantes que fizeram duas palestras importantíssimas abordando de forma bem clara a questão do mundo e da história em que a sociedade viveu ao longo desses últimos anos. Então acredito que se tiver alguma pergunta mais localizada certamente eu posso contribuir. Mas, se for algo que envolva uma discussão maior, eu tive aqui um ótimo aprendizado.

Recebido em Novembro de 2014 Aceito em Dezembro de 2014 